\title{
Incest, Classified
}

\section{A Seventeenth-Century Tibetan Ruler's Perspective on Sexual Proscriptions and the Boundaries of Kinship}

\author{
Jonathan Samuels \\ Associate Faculty Member, Oriental Studies, University of Oxford, \\ Oxford, UK \\ jonathan.samuels@orinst.ox.ac.uk
}

\begin{abstract}
The prohibition on incest, a topic so key to kinship studies, has not featured prominently in literature on Tibet. This article draws attention to a previously unreported section of writing devoted to the topic of incest, composed by the Tibetan 'prime minister' Sangye Gyatso (Sangs rgyas rgya mtsho, 1653-1705), one of the principal architects of the Tibetan state. Sangye Gyatso sets out what purports to be a threefold classification of incest, traditional to Tibet, and considers how aspects of it are to be interpreted. The present article focuses on some of the significant issues raised by this piece. Among these are questions about the context and circumstances of its appearance, the status of incest as a category in historical Tibet, and the place of religious and state authority in the social domain.
\end{abstract}

\section{Keywords}

incest taboo - Tibet - Sangye Gyatso - sexual offence - scholasticism

\section{Introduction}

The topic of incest prohibition has been foundational to kinship studies: anthropological interest in it has also always had a historical dimension. Evidence from societies in previous centuries was used in support of theories about the universality of the incest taboo, such as Morgan's evolutionism and Lévi-Strauss's structuralism (Godelier [2004] 2011: 15). More recently, for those arguing from a cultural relativist standpoint, references to historical examples, 
particularly those of brother-sister marriages in Roman Egypt (Hopkins 1980) and ancient Persia (Herrenschmidt 1994), have become standard ways of demonstrating the lack of absolutes in the domain (for more, see Godelier [2004] 2011: 375-89). The incest prohibitions of any given society, as with its notions of family and relatedness, may appear immutable. Some more recent studies, such as one published in Science (Schulz et al. 2019) investigating how changes to the rules on incest, emanating from the medieval Western Church, may profoundly have shaped the world, ${ }^{1}$ encourage us to appreciate that incest prohibitions have not been immune to the flows of contact and exchange, in terms of which history is increasingly understood.

The Church's involvement ensured that the history of incest prohibitions in some societies has been reasonably well documented. In other cases, where the prohibitions were no less fundamental to notions of human society, the absence of records leaves us uncertain about individual histories. As remarked elsewhere in this volume, one thing that distinguishes Tibetan communities is the unique range of marriage types they embrace. This means an unusually broad understanding of what constitutes a permissible union, and by implication, of the prohibitions circumscribing such things. Academic literature relating to incest prohibitions in Tibet is, however, far from extensive. Historical perspectives also remain largely unexplored. Various ethnographic and anthropological studies about communities labelled 'Tibetan' make reference to incest prohibitions - including Bell (1996); Childs (2004: 98-100); Dargyay (1982: 41); Fürer-Haimendorf (1964: 20-21); Levine (1984; 1988: 41-2, 160-61); Prince Peter (1963); Schicklgruber (1993: 728). But the only studies that foreground aspects of the topic are a few recent ones (Berounský 2019; Buffetrille 2004) investigating the ritual purification of incestuous acts. The scarcity of primary source material partially explains why the topic of incest prohibitions has not yet attracted the attention of historians of Tibet. The emergence of a seventeenth-century section of writing devoted to the subject seems, therefore, noteworthy. The fact that it was composed by Sangye Gyatso (Sangs rgyas rgya mtsho, 1653-1705), the 'prime minister' turned 'regent' of Tibet, only adds to this significance. This piece is highly unusual; no other

1 The study observes that the medieval Catholic Church's obsession with incest led it to 'expand the circle of forbidden relatives' (Schulz et al. 2019:2). The dismantling of traditional kinship structures that this triggered, it proposes, promoted the idea of marriage 'by choice' (Schulz et al. 2019: 2). The study sets out to test the theory that the resulting transformation proved to be 'a key factor behind a shift towards a WEIRDer psychology' (Schulz et al. 2019: 1); that is, the unusual outlook, characteristic of WEIRD (Western, Educated, Industrialized, Rich, and Democratic) societies. 
example of a Tibetan author writing so explicitly about this topic has yet come to light. Ostensibly, the discussion it contains revolves around what purports to be a traditional, threefold division of incest in Tibet. Also featuring conspicuously are references to a supposed 'seven generations' rule: the idea of a specific range of relatedness, within which sexual relations and marriage between individuals are forbidden. Previous academic works make no mention of the threefold classification, but a prohibition lasting seven generations is referred to in many of the aforesaid studies (Aziz 1978: 58 n.12; Childs 2004: 98; Levine 1988: 41 n.7; Prince Peter 1963: 423; etc.) and it has been represented as a Tibetan 'cultural prohibition' (Childs 2004: 98). Aspects of what Sangye Gyatso said about both the threefold classification and the prohibition of seven generations are examined here.

Due to the piece's richness and complexity, it cannot be dealt with in its entirety here. ${ }^{2}$ But in order to evaluate its significance and how much it actually tells us about the Tibetan social realm, some basic questions must first be addressed. To suppose that Sangye Gyatso, in the manner of some early ethnographer, would simply present us with a description of social practices seems naïve. Writing on such matters is uncharacteristic of Tibetan historical authors, and open discussion about aspects of the incest prohibitions seems unprecedented. Hence, identifying the context within which Sangye Gyatso worked and the circumstances that led him to broach the topic are essential. The fact that Sangye Gyatso was a figure of such authority immediately seems pertinent. He was engaged in the process of state-building, prompting him to write, among other things, about law. His promotion of state may also have taken more subtle forms. In 1687, for instance, he masterminded and commissioned a set of paintings that represented Tibetan medical knowledge in a manner with which the ordinary person could readily identify. Within this, Janet Gyatso reads a message to the populace, with the newly institutionalised medical system being portrayed as one that was 'isomorphic with the aspirations of state' (Gyatso 2015: 74). Examining the background behind Sangye Gyatso writing about the incest prohibition allows us to determine in what capacity he approached it and whether it was a way of projecting authority into the sphere of social practices. More generally, it also brings greater clarity regarding the extent to which, in the pre-modern era, the forces of religious and state authority were presences within the Tibetan social domain. The piece also sheds light on the historical status of the category of incest in Tibet.

2 A subsequent study will include a full translation and more comprehensive analysis of the original document. 
Sangye Gyatso was a true giant of Tibetan history, remembered chiefly for his contributions in the medical and political spheres, celebrated as the founder of the modern Tibetan medical system, and together with the 'Great Fifth' Dalai Lama (Ngag dbang blo bzang rgya mtsho, 1617-82) the principal architect of the Tibetan state. Born slightly north of Lhasa, in the valley of Nyangdren (Nyang dran) in 1653 , he originally studied medicine. His talents attracted the attention of the Fifth Dalai Lama, who eventually appointed him Desi (sDe srid), a post akin to that of chief minister, in 1679. When the Great Fifth died a few years later, Sangye Gyatso took charge, making him, effectively, regent. Heading the Ganden Podrang ( $d G a^{\prime}$ ldan pho brang) administration, he adopted the Great Fifth's state-building mantle. Among his most symbolic acts was overseeing completion of the Potala Palace and founding the famous Chakpori (ICags po ri) School of Medicine and Astrology (in 1696), for the training of monks (he himself remained a lay person all of his life).

Fearing that the power vacuum arising from the Great Fifth's death would be exploited, Sangye Gyatso, aged just 29, decided to conceal the news until he had secured the succession of the Sixth Dalai Lama, who was installed in 1697. This forced him, over many years, to perform a complicated political balancing act, playing off the Qing, Kangxi Emperor (1654-1722) and two rival Oirat Mongol groups (the Khoshut and the Dzungar), all of whom were vying for influence in Tibet. To counter Qing influence, Sangye Gyatso forged ties with the Dzungar Khanate, the Inner Asian enemy of the Chinese. But tensions grew when the Khoshut Mongols sought to re-establish their role as guarantors of the Ganden Podrang hegemony. The ensuing power struggle descended into military conflict. Khoshut forces defeated the Central Tibetan army. Sangye Gyatso surrendered, having been offered assurances of safety. But he was murdered by his captors outside Lhasa in 1705, while supposedly being led into exile.

Despite his embroilment in political matters and involvement with law, none of the official interventions made by Sangye Gyatso appear to have involved cases featuring issues of incest or its prohibition. The text in question here must instead be understood as part of his literary output related to scholarly activities. Sangye Gyatso helped institutionalise Tibetan medical learning. In addition to founding the aforementioned medical college, he composed the 'Blue Beryl' treatise (Bai dūrya sngon po), the best-known commentary on the Four Medical Tantras (rGyud bzhi), the medical tradition's principal text. As a discipline and system of learning, medicine (sman) was coupled with tsi (rtsis); a field combining astrological and astronomical knowledge. Between 1683 and 1685, Sangye Gyatso composed the 'White Beryl' treatise (Bai dürya dkar po), a monumental tract on tsi. Following the appearance of the White 
Beryl, an individual identified only as Ngawang (Ngag dbang), from the southern Tibetan area of Chongye ('Phyongs rgyas), wrote a response. This work, the '208 Notices' (Ngag dbang 1976),, 3 consisted entirely of questions, addressed to Sangye Gyatso, probing and challenging the contents of his White Beryl. In direct response to Ngawang's text, Sangye Gyatso penned the 'Purifier of the (White) Beryl (Bai dürya g.ya sel)', bearing the full title, 'Revealer of the True Countenance: the Response that Cleanses the Errors (imputed to) the White Beryl Treatise.4 This systematically addressed each of Ngawang's questions. The section dealing with the incest prohibition, which is introduced simply as 'About incest' (byi nal kyi skor), is one such response.

The tsi tradition is divided into two branches, the so-called 'white' tsi (dkar rtsis), to which Indian origins are attributed, and 'black' tsi (nag rtsis), which is said to derive from China. This division only partly reflects the diversity of this tradition, in which the worlds of Chinese cosmogony, Indian mathematics, tantric morality and Tibetan divination merge. This bizarre combination is an unlikely source of detail about social practices. But the extraordinary hold exerted by organised religion on Tibetan literature meant that there was limited scope for open discussion about what it designated the 'mundane'. Writings of the tsi tradition were one of the few places where the attitudes, values and concerns of the ordinary populace were articulated. It is among discussions about ways to secure success in agricultural activities, business endeavours, the treatment of illnesses, and specifically the organisation of marriages that we encounter Sangye Gyatso's section on incest. Despite the human side to tsi, Sangye Gyatso, like other scholars of the tradition, approached it primarily as a theoretician, concerned less about individual cases than with clarifying the principles, systems and schemes that could facilitate correct calculations.

\section{Fundaments and Sources}

Before examining aspects of the discourse, it is worth reprising what are generally seen as the foundational notions of Tibetan kinship, upon which divisions such as the threefold one are built. Traditionally, the terms 'bone' (rus) and 'flesh' (sha) are used to refer, respectively, to the essential substances transferred from the father and mother to the child. Bone is regarded as dominant, and the term rus refers, metonymically, to the descent group formed by those

3 The text (henceforth referred to as Notices) bears the full title sNga na med pa'i bstan bcos chen po bai dūrya dkar po las 'phros pa'i snyan sgron nyis brgya brgyad pa.

4 The text (henceforth referred to as Purifier) bears the full title, bsTan bcos bai dürya dkar po las dris lan 'khrul snang g.ya sel don gyi bzhin ras ston byed. 
sharing this substance: hence, it also denotes 'clan'. These Tibetan notions are instantiations of a more widespread phenomenon, in which one or more of a small group of bodily elements or products - blood, bone, flesh, sperm, milk, breath (Godelier 2011: 336) - are believed to embody the essence of male or female progenitors. Such theories of substance are also often coupled with notions about transmission and inheritance, with implications regarding consanguinity and prohibitions on substance 'mixing'.

The first credible European account of Tibetan kinship reaches us courtesy of the Jesuit missionary Ippolito Desideri (1684-1733), who was resident in Tibet between 1717 and 1721. In it, Desideri reports that 'The Thibettans recognize two classes of kinship' (de Filipi [1932] 1937: 192), described in terms of the two substances. Of the first, he said, 'They recognize, as relations of Rupa-cik, or of the same bone, those who descend from a common ancestor, even when they are divided into many branches during many generations.' And this form of kinship, 'though it may be exceedingly distant, is looked upon as an absolute and inviolable bar to matrimony'. This he contrasted with kinship of the second variety, that between those who were of 'Scia-cik' or the 'same blood', which he said represented only 'a bar to marriage in the first degree of relationship'. These bars to marriage were evidently prohibitions arising from what was considered incestuous. The mother's substance is subject to rapid dissipation. Within just a couple of generations there are sufficient degrees of separation between those sharing maternal ancestry to allow sexual relations and marriage. Conversely, kinship associated with the father's substance are depicted as immutable. Desideri's description expressly precludes bilateral (or cognatic) descent, whereby ancestry is traced equally through the father's and mother's forebears. He refers to a form of unilineal (specifically, patrilineal) descent. References to the bone-flesh division are scattered throughout Tibetan historical writings from all eras, as are those to the incest prohibition, exogamy, and marriage prohibitions implied by the division. But such references are usually glancing; sources do not elaborate on the theory behind the division. Only with the appearance of anthropological studies, such as Diemberger (1993) and Levine (1984), was the theory of substance fleshed out. Prior to these, Desideri's was seen as the most succinct account of traditional views on the substances and their implications for kinship and marriage. And his remains the most commonly cited historical source on related Tibetan customs. ${ }^{5}$ Sangye Gyatso's section of writing presents us with the clearest expression of indigenous thoughts on the topic outside the modern era.

5 Lévi-Strauss devoted a whole chapter of his Elementary Structures of Kinship to 'Bone and Flesh' ([1949] 1969: 393-405). He proposed that 'From Tibet and Assam to Siberia, and 
Our two main historical sources, Desideri and Sangye Gyatso, were contemporaries, and while they never met, their fates were oddly intertwined. Desideri arrived in Lhasa barely a decade after Sangye Gyatso's death. As the former relates in the chronicle of his travels, ${ }^{6}$ he forged positive ties with the de facto ruler of Tibet, Lhazang Khan (Lha bzang Khan, d. 1717). This was the ruler of the Khoshut Mongols, who, ultimately, bore responsibility for Sangye Gyatso's murder. Desideri's sympathies were entirely with Lhazang Khan and his Khoshut compatriots. But it was the return to Lhasa of their rivals, the Dzungars (Sangye Gyatso's allies), that finally led to Lhazang Khan's demise and ushered in Desideri's final days in Tibet.

\section{$4 \quad$ A Provocative Question}

The works by Ngawang and Sangye Gyatso that contain the question-answer exchange belong to a tsi tradition that had, by the seventeenth century, developed into a scholastic discipline; a process to which Sangye Gyatso's own writings contributed greatly. Drawing heavily from Tibetan Buddhist scholasticism, it was defined by a corpus of works (authoritative scriptures, treatises and commentaries). Similarly informed by Buddhist scholasticism, the discourse attached to it was, increasingly, learned, structured dialectically and concerned with correct interpretation of the corpus. Appeals for clarification or for the reconciliation of apparent inconsistencies gave authors a platform

throughout China, we have met, as the "Leitmotiv" of the indigenous theory of marriage, the theory that the bones come from the father's side and the flesh from the mother's side' ([1949] 1969: 393). Lévi-Strauss depends heavily on Desideri's brief but clear articulation of the Tibetan distinction. In fact, Lévi-Strauss declares that 'we shall acknowledge that we are indebted to the old Italian traveller for the elucidation of an absolutely fundamental notion, the key to any attempt at reconstructing kinship systems in a geographical area of considerable dimensions, but in which widely dispersed survivals suggest an ancient homogeneity that, in these chapters, re-forms before our eyes.' ([1949] 1969: 374). We can gauge, from this, the weight attached to Desideri's comments by Lévi-Strauss. He felt indebted to Desideri for providing both a pithy, epigrammatic expression of the proposed ancient system and some degree of historical 'confirmation' of its existence. The incest taboo and communication between clearly defined descent groups lie at the heart of alliance theory. Desideri's words give the impression of a society in which these are precisely and unambiguously articulated. Although the exact extent to which Desideri's encapsulation influenced or even inspired the development of Lévi-Strauss's views regarding descent groups, marriage exchange and alliance theory is a matter of speculation, that it played a far from trivial part seems beyond doubt.

6 Desideri provides a personal account of the political upheaval that engulfed Tibet at the time (de Filippi [1932] 1937: 146-71). 
for elaborating their thoughts on a particular topic, resolving perceived misunderstandings and occasionally criticising earlier interpretations. The model was irenic; through the resolution of seeming contradictions, it aimed to present the tsi tradition as one grounded in a unified body of knowledge: a particular challenge given the eclectic constituents of that tradition.

Structurally, Ngawang's question conforms with the normal pattern of scholarly discourse. It requests clarification on issues relating to incest. But in presentational terms, it initially seems chaotic. Ngawang appears simply to have gathered every significant reference to incest he could locate in the tradition's various branches. He cites legends, iconographic representations and ritual practices, derived from Indian tantra, Chinese divination and mainstream Buddhist sources, and seems just to be querying how such miscellaneous elements can be combined. Ngawang's question is, in fact, more refined. He alludes to what are evidently differing perspectives and attitudes to incest. He calls for an authoritative voice: one able to reconcile these diverse elements and present the tradition's official line.

But in the second part of Ngawang's request for clarification, he moves to specifics. He cites a threefold classification mentioned by Sangye Gyatso in his White Beryl. This distinguished between so-called 'black', 'white' and 'motley' types of incest. Ngawang also refers to a separate prohibition on unions 'within seven generations' (mi rabs bdun tshun): that is, between those separated by fewer than seven generations. The White Beryl had indeed featured the threefold classification; it had also cursorily mentioned the seven generations. But that treatise had no section dealing specifically with incest or the prohibitions against it, so the question of the two schemes' relations to one another had not arisen. Establishing the correct manner of calculating the seven generations, one that was in accord with the threefold classification and the descent principles underpinning it, has the appearance of a standard scholarly exercise. But Ngawang introduces a third element: that of contemporary marriage practices. He first mentions these in relation to 'various territories, such as mon'. Mon often implies groups outside the Tibetan sphere, ${ }^{7}$ but from the specifics Ngawang provides about the marriage practices, the communities he has in mind are patently Tibetan ones. He suggests that the practices they follow could result in unions between those who are not separated by the requisite

7 Mon frequently denotes the lands inhabited by non-Tibetan ethnic groups who speak Tibeto-Burman languages and have strong affinities with Tibet, especially those residing in present-day Bhutan and Arunachal Pradesh. But it is also used, in a vaguer sense, for communities living on the margins of what is considered 'Tibetan' (either ethnically, politically, linguistically, or culturally). 
number of generations, and consequently are closely related to one another. Ngawang therefore questions, 'Where unions between such males and females occur, has the offense of white incest been sustained or not?'8 And he wonders 'how (such practices) are not deviant?' ${ }^{9}$

The addition of this last element makes the whole exchange an exceptional one, for two reasons. Firstly, through the introduction of this practical matter, the whole discussion is forced outside accepted scholarly parameters. Tibetan scholastics were concerned with the resolution of issues within the textual sphere: the interpretation of canonical works, how various elements within them related to one another, etc. Being pushed to say what these schemes meant on a practical level and having to deal with a potential clash between theory and practice was highly unusual. ${ }^{10}$ Secondly, what makes this exchange remarkable is that it demanded judgement about practices in the social realm. Social rituals were not scholastic territory, and here, neither the practices nor those who performed them could be treated as abstractions: those belonging to the communities following the customs would clearly have recognised themselves as the target of the remarks.

To the uninitiated, Ngawang's disregard for scholarly conventions could seem rational, especially if he had concerns about ignorance unwittingly leading to unions that were, technically, incestuous. But there are reasons for doubting the sincerity of Ngawang's motives. The way that the question was formulated invited Sangye Gyatso to choose between a series of unpalatable responses: either acknowledging that aspects of tradition were irreconcilable with each other, conceding that some were irrelevant to real life, or passing critical judgement on the marriage customs of certain Tibetan communities. Despite the courteous manner in which Ngawang expresses himself, there must be a suspicion that his question was intended as a trap for Sangye Gyatso. Ngawang's Notices blatantly challenges the regent's scholarly authority. Evidence of this is detected in strange places. All of the 208 questions were directed at the White Beryl, but in neither content nor order do they reflect the organisation of the original treatise. Ngawang created the structure of 208 questions that Sangye Gyatso was obligated to follow in his responses. Ngawang's subtle mocking of the regent is encoded in the number he assigns to the section with questions about the anything but holy topic of incest. In a rare example of ironic humour

8 gang zag pho mo sdebs na byi dkar gyi nyes pa phog gam ma phog (Notices, p. 563).

$9 \quad \log$ par ji ltar ( $m i)$ 'gro dogs (Notices, p. 563). The negative that has been omitted from this text's version of Ngawang's question is reinserted in Sangye Gyatso's response.

10 We note certain parallels here with the situation that occurred in the medical sphere (Gyatso 2015: 397-400). 
in the Tibetan textual tradition, Ngawang irreverently numbers the section on incest '108', the most sacred of numbers for Tibetan Buddhists!

In what follows, we examine aspects of the threefold classification and the seven generations prohibition. The third component of Ngawang's question, the specifics of the practices he refers to, will be considered elsewhere.

\section{$5 \quad$ Sangye Gyatso on the Threefold Classification}

Although originally mentioned in the White Beryl, the threefold classification had been afforded no particular prominence. But since Ngawang's Notices asked for clarification, Sangye Gyatso felt obliged to elaborate on it in his Purifier. The classification is introduced in the form of a terse formulation, which is virtually identical in all three works:

The 'white illicit sexual union' (byi dkar) in that (tradition) is the 'white incest' (nal dkar) with one belonging to the maternal group.

Union between those of the paternal group is black illicit sexual union' (byi nag).

Union between mother and son is 'motley illicit union' (byi khra). ${ }^{11}$

Two basic terms are used here for incest. It becomes apparent that, of these, $n a l(b a)$ is the primary one. ${ }^{12}$ The alternative (byi), which I have rendered 'illicit sexual union', does not, in the present context, refer to a broader class of sexual offences; it is used here mainly to avoid circular glossing. More on these terms follows, but essentially, 'incest' is presented as a single category, containing three subcategories: 'black incest', 'white incest' and 'motley incest'. Each subcategory has two alternative designations, depending on which of the two basic terms are used. 'White incest', for instance, therefore, has two equivalent names (byi dkar and nal dkar). The underlying assertion is that incestuous acts can be graded, partly by way of the seriousness of the offence. Incest, in this conception, is primarily defined by consanguinity and in terms of prohibited relations between members of two descent groups, those to which the father and mother respectively belong. Each is a descent group within its own right; that is, one that asserts common ancestry through a shared 'bone'

11 de'i byi dkar zhang po'i nal dkar dang / pha tshan nang sdebs byi nag / ma bu nang sdebs byi khra (Purifier, p. 376).

12 The full, dictionary form of the word is nal $b a$. The single syllable $n a l$ is the contracted form, as appears in compound words. 
(i.e. rus or rus pa) substance. But Sangye Gyatso's explanation employs a concept comparable to the anthropological convention of Ego, although one that is androcentric. From Ego's perspective, his father's descent group is his pha tshan, while his mother's is his zhang po. Ego's pha tshan are those with whom he shares the same bone substance that he inherited from his father. The term zhang po is more familiar as a kinship term denoting a single individual (i.e. a maternal uncle). But here it is used collectively, for the descent group with whom the mother shares bone substance. Generally speaking, none of the three terms mentioned (pha tshan, zhang po, or rus) is used exclusively in relation to unilineal descent. All three crop up in historical writings and contemporary settings. Pha tshan often refers to smaller groups of adult males within two generations (i.e. brothers and father/paternal uncles and grandfather) and zhang po, the eldest maternal uncle. The organisational and political importance of rus ( $p a$ ) means that its range of uses is far wider: it can designate clans, lineages and even single direct lines, such as dynastic or religious lines of succession. But Sangye Gyatso is unequivocal about how the terms should be understood in the present context. He glosses the pha tshan, or paternal group, as a 'clan group' (rus tshan). Thus, groups here are not just close kin or those sharing a household. Furthermore, his discussion about marriage and relations only makes sense if the respective descent groups encompass all those within them who share bone descent, both male and female. Ego's principal affiliation is with this paternal group, those with whom he shares his ancestry in the form of the bone substance. In terms of kinship or relatedness, the other descent group, his zhang po, are described as a 'close (but) secondary branch' (nye ba'i yan lag).

The threefold black-white-motley coding by means of which the subcategories are distinguished is relatively common in Tibetan literature. Normally, it is used as a broad or comprehensive form of categorisation. As such, it occasionally features in legend and ritual, but probably occurs most regularly in medicine, as a typological division of materia medica and nosology..$^{13}$ What differs here is that the black and white indicate comparative distinctions. The connotations, however, are not moralistic per se, and this threefold coding is not religious in origin. Sangye Gyatso explains that the most serious, 'black' variety of incest would occur if Ego had sex with a female belonging to the group with whom he shares bone substance (his pha tshan) - only heterosexual relations feature in the description. If he had sex with someone from his

13 In terms of medical literature, the division is primarily taxonomical rather than hierarchical, according to Tawni Tidwell (pers. comm. 2 July, 2020), an anthropologist who is also trained and practises as an amchi or Tibetan physician. 
mother's descent group (his zhang po), the incest would be 'white'. So, while white contrasts favourably with 'black', it does not imply anything positive. The relative gravity of the misdeed is determined by the logic of patrilineality. Added to these is the third kind of incest: as the name suggests, this 'motley' variety is a more ambiguous category. A pioneering study by Goody (1956: 293) contains an interesting parallel. His analysis of prohibitions on sexual intercourse among groups such as the Tallensi and Ashanti also elicited threefold divisions, ${ }^{14}$ something that Goody saw as deriving naturally from a unilineal descent system. But in the present case, since the black and white varieties of incest seem to cover the basic range of prohibited relations between members of the two descent groups, why is a third, 'motley' category necessary? Even more intriguingly, why is the mother-son relationship singled out for mention? One might think that the closeness and intimacy of the bond provides adequate grounds for separating it from others. But the classification does not seem sensitive to such considerations. And while in other contexts (see below) incest with a mother or sister is regarded equally, according to the patrilineal logic of this classification, the mother and son have inherited different bone substances, so incest between them would be less serious than that between Ego and his sister, or indeed between Ego and his paternal aunt, all of whom share the same bone. Although the type of relationships captured by the motley category require further investigation, a partial explanation for the singling out of the mother-son relationship is supplied by Sangye Gyatso. His discussion of this category branches off into the topic of tantra. The mother-son relationship is often evoked in antinomian tantric writings, and this is one reason why it warrants special mention in the threefold classification. This transgressive aspect might seem, by definition, to place it outside the bounds of Tibetan social custom, but it opens up an interesting avenue in Sangye Gyatso's discussion (covered below), since he must address the issue of how relevant attitudes to incest, as presented in Buddhist canonical works, actually are to Tibetan customs. What becomes clear in the discussion is that neither the threefold classification nor the formula by means of which the White Bery/ introduced it was Sangye Gyatso's own creation. He was merely interpreting material that appeared in earlier sources. Regarding its provenance, Ngawang refers to 'tsitantras' (rtsis rgyud), but it is unclear exactly which texts he means. Sangye Gyatso is more forthcoming: he seems to identify the classification with the 'Old' collection of tantras (the rNying ma rgyud 'bum). This corpus of works is

14 The Ashanti and Tallensi are peoples whose homelands are in present-day Ghana. In addition to his own fieldwork, Goody drew heavily from anthropological studies of Ashanti and Tallensi communities conducted between the 1920s and 1940s. 
closely associated with the Nyingma (rNying ma) school of Tibetan Buddhism and early editions of it probably go back to the twelfth century. Although Indic origins are claimed for the materials it includes, many later scholars disputed its canonical authenticity, partly on the grounds that it contained indigenous (i.e. Tibetan) elements. In this regard, the threefold 'white-black-motley' distinction seems significant. But even if cognate classifications are to be found in Indian, Chinese, or other sources, the version that reaches us via the tsi works has been so thoroughly indigenised as to convince us that it represented more in Tibet than a theoretical scheme. ${ }^{15}$

\section{Terms and Categories: Cross-Cultural, Historical and Linguistic Issues}

Before returning to the text, we should examine the notion of incest, as a category. Goody's aforementioned study (1956) highlighted the dangers of assuming, ethnocentrically, that incest exists as an isolable category, separated from other forms of sexual offence, in cultures other than our own. Whatever might be said about the ubiquity of an incest prohibition and high degrees of correspondence regarding the kinds of relationship it proscribes, there is no universality with respect to the existence of a collective term for such illicit relationships. Goody observes, for instance, that the Tallensi have no designation for incest (1956: 293), whereas Héritier (1999:46) remarks that the ancient Greeks had no explicit term. In neither case does this lead to the conclusion that the category does/did not exist. Goody argues that for the Tallensi, for instance, incest represents an 'implicit classification' (1956: 293). Even if this proposition satisfies us, the existence of a distinct category, designated by an unambiguous term, is still a matter of historical as much as cultural interest. Before making any assertions about social practices in historical Tibet, it therefore seems doubly important to be certain that when Sangye Gyatso and others used the terms already identified, they intended to refer specifically and exclusively to a category equivalent to that of incest. To do this, we briefly examine how the terms and categories have manifested in different spheres (social, legal and literary) and what we learn from this about their relations with each.

The two basic, independent terms our texts use for incest (byi and nal ba) which they sometimes combine to form a compound (byi nal), with the same meaning - appear in the earliest era of Tibetan writing (the imperial period:

15 The later study will investigate the classification's documented history more comprehensively. 
seventh to ninth centuries) and have maintained a relatively high degree of lexical stability, as designations for illicit sexual union. Byi has tended to cover a wider spectrum of sexual relations, not simply those between kin, but also acts that contravene other rules and conventions, especially relating to marriage. $\mathrm{Nal} b a$, however, has been used more restrictively, for sexual union between those considered relatives. 'Incest' (in the form of $\mathrm{nal} \mathrm{ba}$ ), therefore, is a clearly delineated category, and simply by virtue of this fact it stands out in the domain of sexual prohibition. No other sexual offence appears to be distinguished in this way in Tibetan. There is, for instance, no term used exclusively for 'adultery', no separate term for 'fornication', nor is there evidence (until modern times) of a term for the category of 'rape'. All such misdemeanours have regularly been subsumed under notions such as byi. It is possible to distinguish two separate lexicons in Tibetan historical writings relating to illicit sex. The first is made up of terms such as byi and nal ba. The second comprises various terms with origins in organised religion, which have mainly been translated from Sanskrit. These convey value judgements, institutional (largely monastic) prejudices and socially aloof attitudes: the act of sex itself is tainted. From the celibate's perspective it is portrayed as impure, and while the vocabulary for conveying different violations of a sexual nature can be precise, the categories referenced are not socially defined ones, but relate to classes of vows. Sexual misdeeds of lay people are communicated through certain catch-all terms (e.g. $\log$ g.yem), which primarily denote transgressive heterosexual actions. ${ }^{16}$ More specific references to 'deviant' sexual activity (where a chief determinant for the classification as such is the deed's offence to religious sensibilities) include homosexual acts, oral and anal sex and bestiality. But none are distinct categories and there are no separate terms to describe them. Religious literature has no proscriptive designations for the category of incest and generally does not single it out for special treatment. It is one of the many offences subsumed under the aforementioned, vague catch-all categories. Incest is, however, a recurrent narrative theme in certain Buddhist scriptural works, translated from Sanskrit, for which the term nal $b a$ is used. But this is literally the stuff of legend (see below), culturally distant from the Tibetan social context.

These two lexicons of sexual misdemeanour, the popular and the religious, delineate domains and levels of discourse. Terms belonging to the former (including byi and $n a l b a$ ) are distinguished from the religious vocabulary in that they normally surface in discussions with a genuine social aspect. A term like byi may be no less proprietorial in the attitudes it conveys towards females

16 Etymologically, log g.yem has associations with wantonness and prostitution, and carries with it distinctly misogynist undertones. 
than its religious counterpart (log g.yem) but is more reflective of social biases than detached monastic ones. This distinction is reflected in the way that various words in the popular lexicon describe individuals in terms of their social status or their relations with social institutions. Byi, for instance, serves as a stem for various other designations, such as those roughly akin to 'adulterer' (byi po/bo) and 'bastard/illegitimate child' (byi phrug). ${ }^{17}$ The religious lexicon lacks equivalents and any of these lexical stems.

Terms like byi and nal ba also feature in historical materials relating to law. Especially with respect to offences and punishments, these materials favour the popular rather than the religious lexicon. For example, one of the fifteen articles in a work attributed to Situ Jangchub Gyeltsen (Si tu Byang chub rgyal mtshan, 1302-64), known as the Fifteen Decrees Proclaimed by the Turquoise Dragon (g.Yu 'brug sgrog pa'i zhal lce bco lnga) and commonly described as a 'codification of laws', 18 is 'the edict related to the action and recompense of byi' (Byi byas byi rin gyi zhal lce). ${ }^{19}$ Again, byi functions as an umbrella term, roughly equivalent to 'sexual offence'. The explanation of this category shows that it encompasses adultery - literally, byi with 'the wife of another (man)' (gzhan gyi chung $m a$ ) - as well as incest - that is, byi with 'those to whom one is related' ('brel ba'i phyogs). As objects of the latter, it identifies, 'mother or sister(s)' (ma'am sring mo). Byi rin (or byi 'jal) refers to compensation payments for the offence of byi, paid to the husband by the offender, something reported to follow a system instituted during the reign of the seventh-century Tibetan ruler Songtsen Gampo (Srong btsan sgam po). Buffetrille (2004: 6) cites this text's pronouncements as evidence that the misdeeds of adultery and incest were 'treated identically on the penal level'. This does not seem unlikely, but there are presently too many unanswered questions about such documents (including their exact provenance and the extent to which their contents constituted or functioned as codes of law, especially on a Tibet-wide level) to count them as unequivocal proof of this. The huge gaps in our knowledge of the juridical sphere in historical Tibet mean that much remains to be discovered about how sexual offences were conceived of, categorised and punished (and how much consistency there was with respect to any of these).$^{20}$ What can

17 The Bod rgya tshig mdzod chen mo dictionary (Zhang 1993: 1881) defines the first as 'one who has illicit sex with the wife of another' (gzhan gyi chung mar log g.yem spyod pa po) and the second as 'the (boy-)child of those unmarried' (gnyen sgrig ma byas pa'i bu phrug).

18 In bSod nams tshe ring (2004).

19 bSod nams tshe ring (2004: 147).

20 On the Tibetan punishments for byi referred to in the decree, Buffetrille also says, "The punishment consists in exiling the offenders after one of their limbs has been amputated' 
be said is that, to date, there is no evidence of incest having been treated as a separate category of offence in law, nor that the threefold classification was either recognised or had its origins in the legal sphere. ${ }^{21}$

Regarding categories and spheres, mention should also be made of mnol ba, a term that Ngawang's opening question appears to present as an alternative for 'incest'. Although seemingly cognate with $n a l b a$, in most historical writing, this embraces a wider range of illicit sexual actions than just incest, especially those that flout marriage conventions and produce illegitimate offspring. Where the term established itself was in the sphere of ritual; one that must be distinguished from that of religion, where official attitudes to sex and sexual misdemeanours were sterner. The term forms the basis for a whole subcategory of rituals: the 'mnol fumigation' (mnol bsangs): that is, purification rituals for acts of mnol. These rituals are primarily remedial, but their existence is not associated with the claim of any individual or institution to grant forgiveness or offer absolution for such acts. As with other fumigation practices, the language is popular and concepts largely indigenous. The rituals themselves have a strong social, not to say community aspect to them (for more, see Berounský 2019; Buffetrille 2004).

With regard to the history of the category of incest, perhaps the most complex issue, encompassing both linguistic and conceptual aspects, is the relation between the literary and the vernacular spheres. While the notion of incest, embodied in the term nal ba, has remained stable in historical writings, this is at variance with the situation among the plethora of dialects that comprise spoken Tibetan. Most dialects do not seem to have a distinct term for incest, although cognates, such as nal le and nye lu (Bod rgya tshig mdzod chen mo dictionary, p. 1523; Childs 2004: 100) are relatively common for the offspring of illicit unions. The questions that this throws up about the relation between the two spheres and our reading of historical documents, while important, must be addressed later.

We can conclude that in Tibetan thought, incest has held a special place among sexual offences: that of a distinct category. Despite remaining questions relating to the literary sphere, this distinctness seems neither to have been encouraged by nor to owe its origins to legal or religious authorities, and their interest in the category and the language attached to it, and

(Buffetrille 2004: 11). The document actually says that this was the system once practiced in India (sngon rgya gar du). However, the issue is not a clear-cut one, as in a formulation of decrees during the period of the gTsang pa dynasty $\left(15^{6} 5^{-1642}\right)$, there is a very similar description, but this time linked with Tibet (bSod nams tshe ring 2004: 214).

21 But interestingly, the Turquoise Dragon uses the threefold black-white-motley distinction, although this time, with regard to the offence of killing (bSod nams tshe ring 2004: 149). 
consequently their contribution to shaping either, seems limited. The most likely source for the threefold classification, as with the broader category itself, would appear to be social.

In the remaining sections, two facets of Sangye Gyatso's response are scrutinised. The extent to which external authorities (primarily the powers of organised religion and state) were involved in the realm of social practices is something about which previous studies dealing with historical Tibet (outside the modern era) have said little. Elsewhere, the sphere of marriage encompassing not just marriage types, choices of partner and the form of the wedding, but the customs, rules and practices attached to these - is one in which such powers have sought to establish their authority and impose regulation. An exceptional example of this was in medieval Europe. The Church assumed supreme rights by declaring the institution of marriage a sacrament. It also originally looked to the Bible for guidance on rules of incest. But throughout the Middle Ages, it debated, reinterpreted and expanded the rules on incest, producing what some propose are profound effects on Western society (something tested by Schulz et al. 2019). For centuries following, it was the many branches of the Christian Church that dictated what constituted incest. In Anglicism, for instance, the final page of the Book of Common Prayer, produced in 1662 (when Sangye Gyatso was a child), included 'A TABLE of KINDRED and AFFINITY, wherein whosoever are related, are forbidden in Scripture, and our Laws, to marry together.' ${ }^{22}$

This extreme example serves as a counterpoint to the Tibetan situation, where official involvement in the marriage sphere has been minimal. The historical picture is admittedly vague, but the sphere appears to have been governed more by custom, on a local level, than regulation by any external, centralised authority. We see no evidence of attempts to standardise practices according to any religious or state imperative (there was, for instance, no officially sanctioned wedding ceremony) and little sign that either of these unifying powers saw this as their province. In Europe, the Church's intervention and continued involvement in the sphere created rich ecclesiastical and parish records, which are vital sources of information on

22 A reproduction of the Baskerville edition is viewable on the Church of England website: https://www.churchofengland.org/sites/default/files/2019-10/The\%2oBook\%2Oof\%2O Common\%2oPrayer\%201662.pdf. 
official thinking and social practice. Tibet, however, lacked any such interface between marriage and authority. Not only have customs associated with it largely fallen outside the domain of documented history, but marriage itself has rarely been the topic of intellectual discourse; historical writings tell us very little about the actual or theorised relationship between religion and marriage. Part of Sangye Gyatso's response is valuable in what it says about this relationship.

As stated above, in the medieval Church, the Bible was originally consulted for guidance about rules on incest. Several of the sources Ngawang cited in his initial question could also be classified as 'canonical'. But his use of them suggests a very different understanding of the relevance of scripture to this area. Ngawang emphasised the prominence of the theme of incest (as opposed to its prohibition) in Buddhist materials, especially those of Sanskritic origin. He drew attention to the fact that even when incest was not being directly encouraged (as in the antinomian writings), there occasionally seemed to be some fascination with the subject. Among the examples Ngawang cited was the one best known to Tibetans scholars. This was the origin story of the Shakya (Śäkya), who Ngawang describes as the 'clan of the Buddha' (sangs rgyas kyi sku rus). Incestuous relations between brothers and sisters are depicted as foundational in this legend, ${ }^{23}$ and in reference to this, Ngawang calls the Shakyas a group of 'incestuous pedigree' (nal gyi rigs). This legend had reached Tibet through translated scriptural works, prior to which it had figured in writings throughout the Buddhist world over many centuries, where scholars generally seemed more inclined to highlight than downplay the portion of it recounting the offending acts. Tibetan scholars continued this tradition, and the account became standard in histories of Buddhism.

In addressing the Shakya legend and the other examples cited by Ngawang, Sangye Gyatso's response initially followed the customary exegetical line; he sought to contextualise each in turn. But since the main question he had to tackle was whether these references had any bearing on Tibetan social customs, he specifically addressed the matter of tantric practices, particularly those with antinomian leanings, declaring that:

These are statements addressed to persons who have taken empowerment in the path of secret mantra (i.e. tantra) and have embarked upon the (associated) behaviour; those such as bodhisattvas who are on the

23 For more on the account and its sources outside the Tibetan tradition, see Silk (2008). 
grounds, or persons who are on the verge of entering that path.... They were not directed at everyone. ${ }^{24}$

That is, these references to incest were aimed at individuals who were (in summary) either highly advanced spiritual practitioners or those who had consciously decided to step outside the framework of accepted social norms: for the lives of the ordinary person, such things had no relevance. But then widening the social contextualisation beyond tantra, Sangye Gyatso chose to refer to various examples of what he called 'local customs' ( $y u l$ srol) associated with marriage. Here, he pointed to regional variations and how the traditions of one community may clash with those of another. He even referred to Mongolians who, from the Tibetan perspective, were taking their 'female relatives' (ma'i spun) as wives. This prompted him to wonder what set of standards there were for judging correct practice in this domain, specifically with regard to what constituted incest. One of his conclusions is worth quoting in full: ${ }^{25}$

It is difficult to talk in absolute terms (in the face of) practices that vary by locality. Also, (whichever of the Buddhist codes) such (customs) are considered in terms of, (be it that of avoiding) the ten non-virtuous actions, the (five) heinous deeds, (actions) that are deemed root downfalls for those who have taken empowerment in the secret mantra mandala, or, in the system of the 'individual liberation' (prätimokșa), those (actions covered by the classes of vows) such as 'root' downfalls (pārājika) and 'remainders' (samghāovaśeșa) of the fully-ordained monk (bhikșu), they are not, according to the letter, in even the slightest sense, infractions.... $[\mathrm{W}] \mathrm{e}$ see no (pronouncements) about them in the sūtras or tantras. ${ }^{26}$

In these and other remarks in the section, Sangye Gyatso confirms the state of affairs already suspected; Buddhism's involvement in the realm of social practices was limited. As such, his observations are useful in a historical sense.

24 de dag gsang sngags kyi lam la dbang bskur zhing spyod pa la gshegs pai gang zag byang chub sems dpa' sa la gnas pa'am de min kyang lam gyi sna zin pa'i gang zag.... kun la de ltar ma gsungs (Purifier, p. 375).

25 Throughout Sangye Gyatso's dense text there are numerous references that will mean little to those unfamiliar with the technicalities of Tibetan Buddhism. The section cited here includes a number of Sanskrit terms, but I have refrained from attaching notes explaining content that is extraneous to the gist of what Sangye Gyatso says.

26 rang rang yul srol bcas mtha' gcig tu dka' zhing / de dag gang yang mi dge bcu dang mtshams med lnga gsang sngags kyi dkyil dkor du dbang bskur ba rtsa gtung so thar gyi dge slong la 'dul ba'i rtsa ba lhag ma sogs nas gzhal na nyes dmigs zur cha yang ji ltar gsung ba ltar min / ... des rung mdo rgyud nas gsungs pa ma mthong (Purifier, p. 376). 
But even more notable than his clarification of the situation is his attempt to rationalise it. In Tibetan scholarly literature, spiritual goals and values are generally represented as normative. Marriage is depicted as functional: one of the necessary mundanities of human existence. As such, it has no religious status. Because marriage practices are defined by a set of 'inferior' motives, on the rare occasions that scholars speak of them, they usually do so dismissively. Despite their proclaimed disinterest in these 'worldly' practices, scholars still wished to assert nominal religious dominion over the sphere. Sangye Gyatso's characterisation of relations is, therefore, interesting. He portrays Buddhism as an organised religion; one rooted in a scriptural corpus and, as embodied in its various codes of action and sets of vows, a tradition of discipline. He suggests that what it offers, therefore, is primarily prescriptive and that besides, perhaps, the injunction against 'sexual misconduct' (log g.yem) - one of the 'ten nonvirtuous actions' - none of its strictures relate to the marital domain. Sangye Gyatso goes on to conclude that Buddhism can offer no guidance regarding correct practice in this sphere, and specifically with regard to what constitutes incest, it is to other traditions (including various branches of $t s i$ ) that one must turn. His characterisation of Buddhism here could be questioned, but the acknowledgement that there are some matters about which it simply has nothing to say, and indeed, provinces in which it has no jurisdiction is, nevertheless, significant. Throughout this section he seems to be advocating that rather than being viewed as a subordinate to religion, the marriage sphere should be understood as a parallel one. The religious paradigm, with its absolute values, he suggests, is simply inappropriate when it comes to social customs.

\section{The Seven Generations and Prohibited Degrees of Kinship}

The threefold classification describes the incest prohibition in terms of possible relations between members of two descent groups. A seven generations rule suggests another dimension to calculations, with unions between individuals separated by seven generations or fewer being forbidden on the grounds that they would be incestuous. Ngawang wondered how the two were compatible, and Sangye Gyatso's conclusion about the relation between religion and local custom served as preface to his response. The seven generations issue has two interesting features. First, despite Sangye Gyatso's assertion that Buddhism had nothing to offer on such matters, the many references to the seven generations in Tibetan historical writing are remarkably similar to those in Buddhist Indic (primarily Sanskrit) literature, translated into Tibetan. Secondly, the reports in anthropological studies mentioned above 
confirm that the notion of a seven generations prohibition still means something to certain Tibetan communities. Analysing Sangye Gyatso's response, therefore, promises to reveal more about the relationship between textual traditions and about how a commonly recurring figure within them is salient to the social practices of present-day communities.

The exchange between Ngawang and Sangye Gyatso has certain parallels with (and important differences from) one in medieval Europe, reported in Bede's Ecclesiastical History of England (composed c. $73^{1} \mathrm{CE}$ ), in which Augustine is said to have posed a series of questions to Pope Gregory regarding the Church's stance on specific issues relating to sex and marriage. In the fifth question, he queried, 'Within what degree may the faithful marry their kindred?' (Bede 1969: 85). In this, he was asking how prohibited degrees were to be interpreted in lands with pre-existing customs. Although the nature and dynamics of authority in the two exchanges differ fundamentally, Ngawang, like Augustine, was requesting clarification of the official position on prohibited degrees of relationship and querying whether concessions were to be made among communities outside the central region, which had their own local customs. The specifics of the local customs issue in Sangye Gyatso's response will be dealt with elsewhere. The more basic matter addressed here is the identification of the seven generations, something that is anything but selfexplanatory, as is best illustrated through reference to the situation in medieval Europe. The Church used two systems for reckoning degrees of consanguinity at different times, the Roman and the Germanic. The Roman system meant 'counting the number of acts of generation between ego and alter' (Goody 1983: 136). So, Ego was related to his parents in the first degree, his sister in the second, etc. By contrast, the Germanic system was based on 'the unity of the sibling group, the members of which were related in the first degree' (Archibald 20o1: 28-9; Goody 1983: 136). Thus, the generation, instead of being an act, was the sibling group. Using the analogy of the human body, these generations were the 'joints', separating the head from the finger-nails. While the Roman system 'counted only the generations from the common ancestor, the latter computed the number of degrees by ascending from the base line to the common ancestor, then descending to the relative in question' (Goody 1983: 136). Beginning in the late eighth century, the Church gradually began shifting from the Roman to the Germanic system and insisted that the number of prohibited generations should be seven. This effectively doubled the range of prohibited degrees, since the seventh degree in the German system corresponded to the thirteenth or fourteenth of the Roman (Goody 1983). This and various other revisions introduced by the Church meant that, by the twelfth century, the rules on incest were extended to ludicrous lengths' (Archibald 2001: 27). Both 
the high and the low were confronted with the same problem. Unions that had been acceptable were now ruled incestuous, and with the pool of eligible partners dramatically reduced, people were forced to look further afield, outside traditional marriage networks. It is this that has, according to some, (as already alluded to) left lasting effects on Western society.

As this example demonstrates, the claim that a rule of 'seven generations' applies, in itself, tells us little. A number is not a method of calculation; the latter depends on agreed definitions and parameters. In historical writings from Tibet, the most consistent references to the seven appear in translated Buddhist scriptural and commentarial works. This example in the Jātakanidāna, recounting one of the Buddha's previous existences, is typical:

There resided a brahman named Sumedha. He had entered the womb of a father and mother who were both of good family line: those that the seven generations of which had been subject neither of argument, dispute, nor slur, and which were entirely pure. ${ }^{27}$

Since the life of the Buddha served as a prototype for Tibetan hagiography, when relating the pedigree of native religious figures, Tibetan authors unsurprisingly chose to express themselves in similar terms. The biography of Tsong Khapa (1357-1419), for example, says, of his 'clan' that 'The genealogical lines of their relations were unbroken for seven generations. ${ }^{28}$ Here, Brahmanical thought clearly found a conduit into Tibet through Buddhist literature. The seven generations theme appears in early Indic writings and notably features in the classical Dharmaśāstra treatises, where the notion of the sapinda was developed. The sapinda is the relationship that binds blood relatives: unions between those sharing it would generally be regarded as incestuous. As an organising principle, the sapinda continues to the present day (it is enshrined in Indian law) but has been subject to many interpretations. The Dharmaśāstra generally agree that the sapinda extends 'to six generations either side of the father, and five either side of the mother' (Johnson 2010), although the seventh generation is still commonly cited as marking the outer bounds of the sapinda relationship. Indic notions of the seven generations obviously influenced Tibetan authors. In hagiographical writings, we also find a viable route into

27 der yang bram ze blo gros bzang po zhes bya ba gnas so/ / pha dang / ma gnyis ka'ang rigs bzang ba'i mngal du zhugs te / rigs bdun rgyud kyi bar du gzhan gyis rtsod pa dang / sbyo ba dang / smod pa med cing rnam phar dag go (Gaffney 2018: 4). The Tibetan version is said to have been translated from Pāli rather than Sanskrit.

28 bdun rgyud ma chad pa'i gnyen dang snag gi gnyen mtshams kyang shin tu rgyas pa zhig ste. (mKhas grub dge legs dpal bzang 1982: $5^{-6}$ ). 
Tibetan popular consciousness. But we should be wary about making inferences regarding Indian influences on Tibetan practices in the social sphere. Cross-culturally, references to seven generations of ancestry are so ubiquitous that it must be regarded as a floating trope; its appearance in any single cultural setting may also derive from multiple sources rather than a single one. To plot specific historical channels, it is necessary to look at the substance behind the references. In Tibetan historical writings, a reference to the seven generations eventually established itself as a byword for pure origins: an assertion that the individual's ancestry was unblemished by cases of incest and that knowledge of parentage and genealogy was certain enough to ensure that inadvertent instances could not have occurred. But there is little to suggest that what Tibetans had adopted was anything more than a literary idiom. The Indian treatises dealing with systems of calculating prohibited degrees of relationship appear not to have been translated into Tibetan. Also, despite Tibetan scholars' penchant for identifying India as the wellspring of civilised culture, neither Sangye Gyatso nor Ngawang acknowledge it as the source of a seven generations rule: instead, they associate the seven generations with both tsi and Tibetan traditions. Both interlocutors are clearly focused on how the seven generations should be understood in indigenous terms. Their exchange contains no references to earlier discourse on this matter, nor any established system for calculating the seven. The last point seems significant, since appraising the best 'method of calculation' (rtsis khog) for any given area was the stock in trade for scholars of $t s i$.

In identifying the seven generations and attempting to spell out what they meant with regard to kinship, Sangye Gyatso is something of a lone Tibetan voice. In addition to delineating the generations, he needed to explain how they applied to the system of unilineal descent implicit in the threefold classification. Assuming that the seven were generations of ancestors, around which calculations of kinship were these organised? How was ancestry reckoned? Desideri, we recall, described a system of unilineal descent, with shared 'bone' representing an inviolable bar to matrimony, however many generations separated individuals, whereas shared flesh or blood was only 'a bar to marriage in the first degree of relationship'. He made no mention of seven generations, and it did not obviously fit with the reckoning of which he talked. His account can be compared with the modern description of the traditional system by a native Tibetan, Sagong Wangdu, who states:

If one is related through the father's side, however many generations might have passed, marriage is impermissible. If one is connected 
through the mother's side, marriage is impermissible for 'the three major and three minor joints'; that is, six generations. ${ }^{29}$

This largely concurs with Desideri's version. But Sagon Wangdu's generational bar relating to kinship traced through the mother is higher than Desideri's: the number comes closer to seven generations and is also reminiscent of the sapinda count. ${ }^{30}$ What both descriptions agree on is that generational limits do not apply to consanguinity traced through the father's side, and despite the aforesaid difference, both generally seem congruent with the distinction between black and white incest. On first reading Sangye Gyatso's identification of the seven generations and his explanation of how it is compatible with the threefold classification, therefore, we might be somewhat taken aback. He states:

The question is answered thus. The manner in which one calculates who is included within seven generations (of Ego) according to the 'intention' of the black tsi tradition and our own treatises is one that keeps, without altering, the paternal unit or clan group as its basis and treats the maternal group like a close (but) secondary branch ... We can understand from the way that it explains things here that when calculating who belongs to one's (kin) group, it is those who are encompassed by the seven generations of the father, ancestor, great ancestor, the son, indirect male descendent, and great indirect male descendent, as well as the individual (Ego) himself. But this is not the way of calculating (relatedness) on the maternal side. ${ }^{31}$

29 pha rgyud thog nas gnyen tshan yin phyin / mi rabs ga tshad phyin min la ma bltos par gnyen sgrig byed srol med // ma rgyud nas gnyen tshan gyi 'brel ba yod pa yin na / tshigs chen gsum dang tshigs phreng gsum zhes mi rabs drug ma phyin par gnyen sgrig byed srol med (Sa gong dbang 'dus 2003: 74).

30 I found knowledge of 'the three major and three minor joints' (tshigs chen gsum dang tshigs phreng gsum) sketchy among informants. But this appears to be a mnemonic for these six generations, which literally denotes the three joints of the arm and the three of the finger. In these 'joints' we see some a metaphoric similarity with the Germanic system of calculation.

31 dri lan ni / nag rtsis dang rang gzhung gi dgongs pa'i mi rabs bdun tshun rtsis khog tu gtogs pa'i tshul ni pha tshan nam rus tshan sor bzhag gi dbang du mdzad cing / zhang po ni nye ba'i yan lag lta bur 'byung mod / ... der yang pha dang mes po yang mes gsum dang / bu dang tsha bo yang tsha gsum dang / kho rang ngo bo bcas bdun brgyud du gtogs pa'i mi rigs rtsis khog tu 'jug pas rtogs shing / zhang rigs sogs rtsis khog tu de ltar mi 'jug (Purifier, p. 376). 
Sangye Gyatso categorically asserts, therefore, that the seven generations have nothing to do with calculating relatedness through Ego's mother. He argues that such a depth of knowledge of maternal forebears is neither required nor particularly relevant to distinguishing between eligible and ineligible partners. Instead, he says, the seven are to be understood purely in terms of paternal ancestry and kinship defined by this. But here there is a real departure from other sources, all of which either claim or imply that there is no cut-off point for bone-kinship: sexual acts between those who share an eighth- or ninthgeneration paternal ancestor, just like those with a second- or third-generation one, are incestuous. Sangye Gyatso suggests that this is not the case. But even more striking is his identification of the seven generations. Sangye Gyatso uses two key terms here, one that is usually translated as 'ancestor' (mes po) and its counterpart in this scheme, 'indirect male descendant' (tsha bo). He employs these to convey 'grandfather' (mes po), 'great grandfather' (yang mes), 'grandson' (tsha bo) and 'great grandson' (yang tsha). Hence, Sangye Gyatso's explanation is purely in terms of the direct line. Most surprising of all, Ego is placed at the axis of these lineal ancestors and descendants. This appears to transform the nature of claims that evoke the seven generations. No longer are they retrospective declarations about the unsullied nature of an individual's pedigree (as clearly intended in hagiographical writings). Now, it would appear, the non-incestuous guarantee stretches back no further than the great grandfather and is projected (very questionably) into the future, but only as far as Ego's great grandsons! In reality, Sangye Gyatso intends nothing so farcical. His explanation downplays the sense that the seven be understood in terms of prohibitions, as some sort of outer boundary marker separating illicit from legitimate unions. He instead presents the seven generations as a framework within which kinship should be conceived. He cites various branches of the tsi tradition, which also understand the seven in this way. Within these he includes the system of 'funerary calculations' (gshin rtsis). This branch is distinguished from that of 'marriage [literally 'bride'] calculations' (bag rtsis) and has its own perspective on relatedness, in its delineation of ritual obligations of the living to their deceased kin. We note that the Dharmaśästra understanding of the consanguineous (i.e. sapinda) relationship finds its fullest expression in the pinda offerings made by blood relatives to 'ancestors' (pitr) during the funerary rites. Distinguishing between Indian, Chinese and indigenous Tibetan elements in the 'funerary calculations' is complicated, but Sangye Gyatso only turned to such sources to justify his interpretation of the generations. His real aim, it must be remembered, was to reconcile the various elements that Ngawang suggested were incompatible. He apparently wished especially, to find some way of accommodating, rather than condemning, 
the local marriage practices that Ngawang proposed could lead to incestuous unions. Sangye Gyatso's solution essentially lowers the bar with regard to the patrilineage. He suggests that bone-kinship does not, in perpetuity, represent a barrier to marriage. In fact, individuals need look back no further than the generation of their great grandfathers; even those who knowingly shared a paternal great-great-grandfather could, in theory, marry. How exactly Sangye Gyatso applied this to the local practices must be discussed elsewhere. But in addition to identifying the figure of seven with the bone kinship, like Desideri, he essentially argued that shared flesh-relationship only represented a bar to marriage in the first degree, thus preserving the disparity of the bone-flesh division.

All this appears to challenge traditional understanding of the implications of bone-kinship. But let us consider the matter in practical terms. Maintaining genealogical records stretching back many generations, especially those that are reliable and detailed enough to guard against unwitting cases of incest, by keeping track of collateral kin and their offspring may not be as easy as is sometimes imagined. It requires agreement about who counts as an ancestor and a method of calculation. Some technological aid also seems necessary. In medieval Europe, it was the changing rules of incest that galvanised genealogy, transforming it into a 'literate activity' (Goody 1983: 145). In cases where the written medium is not utilised, sophisticated mnemonic devices would seem essential. Historical records related to a few prominent Tibetan ruling families and religious dynasties have fuelled the idea that even on the popular level, Tibetan genealogical knowledge was, in centuries past, deep. Evidence to substantiate this is difficult to find. Among some communities, rudimentary records of lineal ancestors (i.e. direct patrilines) have been kept, but as yet there is no sign that records or systems complex enough to track collateral lines stretching back over numerous generations were developed. This information should be taken into account when interpreting what Sangye Gyatso said. His challenge was to reconcile textual formulation with popular practice. To achieve this, he undoubtedly exploited the vagueness surrounding the meaning of the seven generations. He chose a gloss for the trope that gave licence to the continuation of the supposedly errant local customs. Given his clear sensitivity to popular sensibilities, for him to explain kinship in a manner that clashed with popular understanding would seem incongruous. It is more reasonable to infer that, rather than seeking to redefine the circle of kinship totally (and by implication, reducing the range of relationships classifiable as incestuous), Sangye Gyatso sought a closer alignment between text and practice by interpreting the former in a manner that reflected social reality. Thus, 'seven generations' was not a literal frame for calculations: it was just 
a way of describing kinship delineated by genealogical memory. This would mean that the genealogical knowledge of those who Sangye Gyatso addressed stretched back no further than two or three generations. There are undoubtedly regional as well as historical dimensions to such questions (see Samuels 2016), but the current variations in descent models among communities described as 'Tibetan' cannot be seen as recent developments. The accounts of Desideri and Sagong Wangdu present Tibetan customs as a picture of uniform practices organised around a unilineal model. And although separated by several centuries, neither can be understood as reflecting the reality of their respective eras. Documentary evidence suggests that descent in the central Tibet of Sangye Gyatso's times, like today, was bilateral. While the exercise of extrapolating from the past to the present should be approached cautiously, one suspects that the situation regarding the place of the seven generations was also probably similar. Heidi Fjeld (pers. comm. 21 March, 2020) confirms that for the central Tibetan population of Panam, references to the seven generations persist, but rather than literal calculations, these serve as metaphors for 'all relatives you know about'. There remains the possibility that reports of a seven generations prohibition among communities outside the central regions have some substance. But in the absence of any evidence to support this, it seems likely that the situation in Panam is replicated elsewhere. That is, while reference to the seven generations may be an important element of tradition, it is not to be understood as indicating deep genealogical knowledge, let alone strict adherence to rules on incest organised around such a count.

More importantly, Sangye Gyatso obviously treated the seven generations as malleable. The exchange indicates that there was no scholarly agreement about what they stood for, but also suggests the same was true on the popular level. In actuality, we have no reason for believing that there was any standardised way of calculating the prohibited degrees in relation to marriage. The exchange was premised on the immutability of the threefold classification of incest and the seven generations, but the mere fact that it proved necessary to interpret these and reconcile local custom with them is a testament to regional variation, undermining any sense that we can talk about an entirely uniform set of Tibetan social practices at the time.

\section{9}

\section{Conclusions}

It has been argued that one of Sangye Gyatso's projects in the field of medicine was bridging the gap between 'theory and practice' (Gyatso 2015: 400) and that part of his challenge was demonstrating how a rational system, much 
influenced by Buddhist scholasticism, applied to the quotidian concerns of the population. Tsi was the sister topic to medicine, and aspects of the exchange between Sangye Gyatso and Ngawang perhaps suggest a corresponding process, with efforts to reconcile scholastic and popular understanding. But while Ngawang's interrogation deploys (or mimics) scholastic technique, the items he questions are very far from the 'hallowed categories' (Gyatso 2015: 400) derived from Buddhist scholasticism. They had neither been created by nor theorised about by the scholastic tradition, and their relationship with it is nothing if not ambiguous. The scrutiny that the exchange brought to the seven generations largely succeeds in demonstrating the absence of any theory or indeed substance behind the slogan.

Sangye Gyatso's work is not an easy read. It is so deeply embedded within a specific context that it is impossible simply to extract information from it about historical practices. It does, however, bring to light a scholarly discourse of which we had previously been completely unaware: that pertaining to social practices surrounding legitimate unions and marriage. Simultaneously, it demonstrates that the category of incest occupied a special place in the Tibetan imagination. Sangye Gyatso's clarification about the marriage sphere's relation with religion (reinforced here by references to the medieval European counterpoint) pre-empt any assumption that this sphere was one that deferred to religious authority.

In explaining both the variety of marriage types in Tibet and the prevalence of unusual ones (especially polyandry), much emphasis has been placed upon economic factors, particularly the scarceness of resources. Elsewhere in this volume (see Fjeld), it is proposed that Tibetan kinship ideology must be understood in terms of its inherent flexibility. Another key component of this ideology is attitudes to incest prohibition. Flexibility cannot be accounted for in terms of vacancies in the socio-cultural landscape. The fact that Tibetans did not experience the intrusion of an institution comparable to the Church in Europe cannot explain their thinking and behaviour. At the same time, accounts that fail to consider the role of unifying forces - either as absences or as presences - in shaping psychology and practices in this sphere are inadequate ones.

What may be regarded as the most valuable contribution of this piece by Sangye Gyatso is that it establishes a distinct place within the historical narrative for the sphere of social practices. Far from being identified with frivolousness, local customs relating to marriage, specifically determining what counts as an eligible union, are shown a degree of respect. But while this goes some way to confirming the sphere's independence, especially from the influence of religion, the picture is categorically not one of uniformity. The discourse may overtly be framed as one that addresses the gulf between text and practice, but is clear evidence of a lack of standardisation and what can only be interpreted as regional variation. 


\section{Acknowledgments}

I wish to express gratitude to Eveline Bingaman, Heidi Fjeld, and Nancy Levine, my co-editors for this special section. I also thank the Inner Asia reviewer for some useful feedback.

\section{References}

Archibald, E. 2001. Incest and the Medieval Imagination. Oxford: Oxford University Press.

Aziz, B. 1978. Tibetan Frontier Families. New Delhi: Vikas Publishing House.

Bede, the Venerable Saint. 1969. Ecclesiastical History of the English People (eds B. Colgrave \& R.A.B. Mynors). Oxford: Clarendon Press.

Bell, C. 1996. The People of Tibet. New Delhi: Motilal Banarsidass.

Berounský, D. 2019. Burning the incestuous fox. A Tibetan fumigation ritual (wa bsang). Études mongoles \& sibériennes, centrasiatiques \& tibétaines 5o. https://doi .org/10.400o/emscat.3782.

Buffetrille, K. 2004. Pilgrimage and incest: the case of mchod rten nyi ma. Bulletin of Tibetology 40(1):5-38.

Childs, G. 2004. Tibetan Diary: From birth to death and beyond in a Himalayan valley of Nepal. Berkeley (CA): University of California Press.

Dargyay, E. 1982. Tibetan Village Communities. Warminster: Aris \& Phillips.

de Filippi, F. (ed.) [1932] 1937. An Account of Tibet, The Travels of Ippolito Desideri of Pistoia, S.J., 1712-1727. London: George Routledge \& Sons.

Diemberger, H. 1993. Blood, sperm, soul and the mountain: gender relations, kinship and cosmovision among the Khumbo (N.E. Nepal), in T. del Valle (ed.), Gendered Anthropology: 88-127. London: Routledge.

Fürer-Haimendorf, C. von. 1964. The Sherpas of Nepal, Buddhist Highlanders. Berkeley (CA): University of California Press.

Gaffney, S. 2018. sKyes pa rabs kyi glen gźi (Jātakanidāna): A critical edition based on six editions of the Tibetan bKa' 'gyur. Oxford, NZ: Indica et Buddhica.

Godelier, M. [2004] 2011. The Metamorphosis of Kinship. London: Verso.

Goody, J. 1956. A comparative approach to incest and adultery. British Journal of Sociology $7(4): 286-305$.

Goody, J. 1983. The Development of the Family and Marriage in Europe. Cambridge: Cambridge University Press.

Gyatso, J. 2015. Being Human in a Buddhist World. New York (NY): Columbia University Press.

Héritier, F. 1999. Two Sisters and Their Mother. New York (NY): Zone Books. 
Herrenschmidt, C. 1994. Le xwêtôdas ou 'marriage incestuous' en Iran Ancien, in P. Bonte (ed.), Épouser au plus proche. Inceste, prohibition et stratégies matrimoniales autour de la Méditerrantée. Paris: École des Hautes Études Sciences Sociales, 113-25. Hopkins, K. 1980. Brother-sister marriage in Roman Egypt. Comparative Studies in Society and History 22(3): 303-54.

Johnson, W.J. 2010. A Dictionary of Hinduism. Oxford: Oxford University Press.

mKhas grub dge legs dpal bzang. 1982. rJe btsun tsong kha pa chen po'i rmad du byung ba'i rnam par thar pa dad pa'i 'jug ngogs. Xining: mTsho sngon mi rigs dpe skrun khang.

Lévi-Strauss, C. [1949] 1969. The Elementary Structures of Kinship. Boston (MA): Beacon Press.

Levine, N. 1984. The theory of rü kinship, descent and status in a Tibetan Society, in C. von Fürer-Haimendorf (ed.), Asian Highland Societies in Anthropological Perspective: $5^{2-78}$. New Delhi/Jalandhar/Bangalore: Sterling Publishers.

Levine, N. 1988. The Dynamics of Polyandry. Chicago (IL): University of Chicago Press. Ngag dbang. 1976. sNga na med pa'i bstan bcos chen po bai dūrya dkar po las 'phros pa'i snyan sgron nyis brgya brgyad pa (208 Notices), in Sangs rgyas rgya mtsho. Dris lan 'khrul snang g.ya' sel (Volume II): 469-6oo. Dehradun: Tau Pon Sakya Centre.

Prince Peter of Greece and Denmark. 1963. A Study of Polyandry. The Hague: Mouton.

Sa gong dbang 'dus. 2003. 100 bod mi'i yul srol goms gshis. Beijing: Mi rigs dpe skrun khang.

Samuels, J. 2016. Are we legend? Reconsidering clan in Tibet. Revue d'Etudes Tibétaines 37: 293-314.

Sangs rgyas rgya mtsho. 1998. Bai dūrya dkar po. Beijing: Krun go'i bod rig pa dpe skrun khang.

Sangs rgyas rgya mtsho. 1976. Dris lan 'khrul snang g.ya' sel(Volume II). Dehradun: Tau Pon Sakya Centre.

Schicklgruber, C. 1992. Grib: On the significance of the term in a socio-religious context, in S. Ihara \& Z. Yamaguchi (eds), PIATS 4: 723-735. Narita: Naritasan Institute for Buddhist Studies.

Schulz, J.F., D. Bahrami-Rad, J.P. Beauchamp \& J. Henrich. 2019. The Church, intensive kinship, and global psychological variation. Science 366(6466): 1-12.

Silk, J. 2008. Incestuous ancestries: the family origins of Gautama Siddhārtha, Abraham and Sarah in Genesis 20:12, and the status of scripture in Buddhism. History of Religions 47(4): 253-81.

bSod nams tshe ring (ed.). 2004. sNga rabs bod kyi srid khrims. Beijing: Mi rigs dpe skrun khang.

Zhang, Yisan (ed.). 1993. Bod rgya tshig mdzod chen mo. Beijing: Mi rigs dpe skrun khang. 